ENTREPRENEURSHIP AND SUSTAINABILITY ISSUES

ISSN 2345-0282 (online) http://jssidoi.org/jesi/ 2020 Volume 8 Number 1 (September)

http://doi.org/10.9770/jesi.2020.8.1(73)

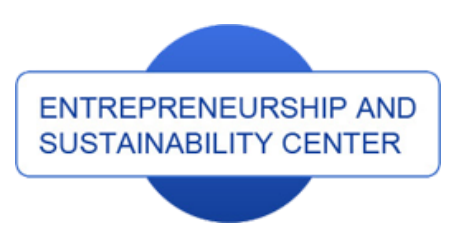

Publisher

http://jssidoi.org/esc/home

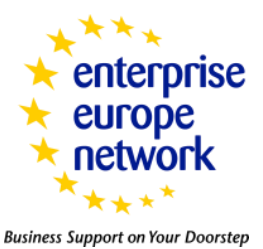

Business Support on Your Doorstep

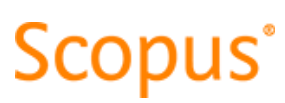

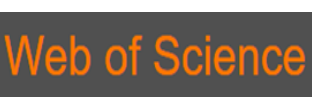

Clarivate
Analytics

\title{
SUSTAINING INNOVATIVE CAPABILITIES OF LIGHT EMITTING DIODE (LED) MANUFACTURERS THROUGH DYNAMIC ENTREPRENEURSHIP*
}

\author{
Suhana Mohezar ${ }^{1}$, Ainin Sulaiman ${ }^{2}$, Mohammad Nazri ${ }^{3}$, Safiah Omar ${ }^{4}$ \\ Faculty of Business \& Accountancy, University of Malaya, Jalan Pantai, 50603, Kuala Lumpur, Malaysia 1,3,4 \\ Social Advancement and Happiness Research Cluster, University of Malaya, Jalan Pantai, 50603, Kuala Lumpur, Malaysia ${ }^{2}$

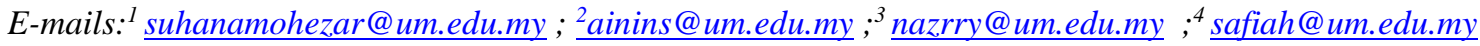

Received 10 January 2019; accepted 10 June 2020; published 30 September 2020

\begin{abstract}
This study aims to explore how dynamic entrepreneurship would contribute to an organisation's innovative capabilities. Using samples from the Malaysian Light Emitting Diode (LED) manufacturing industry, this study conducted semi-structured interviews with four local companies, involving 17 respondents holding various designations and levels. Data collected were transcribed and content analysis was conducted to group the themes and categories. The findings indicate that entreprenurial attitudes and ethusiasm, corporate culture and empowerment, cross-functional teams, customer integration, supplier integration, communication, trust resource and knowledge sharing as some of the important domains emphasised in order for a company to reap the benefits of dynamic entrepreneurship. The findings of this study could help the local companies to understand how, as entrepreneurs, they could move forward from small scale to contract manufacturers by addressing the innovation capabilities through dynamic entrepreneurship. This is important, as failure to satisfy these requirements, may lead to them being excluded from the global supply chain.
\end{abstract}

Keywords: dynamic entrepreneurship, innovative capabilities, supply chain collaboration, light emitting diode, developing country

Reference to this paper should be made as follows: Mohezar, S., Sulaiman, A., Nazri, M., Omar, S. 2020. Sustaining innovative capabilities of light emitting diode (led) manufacturers through dynamic entrepreneurship. Entrepreneurship and Sustainability Issues, 8(1), 1095-1107. http://doi.org/10.9770/jesi.2020.8.1(73)

JEL Classifications: M14, O32

\footnotetext{
* This research was supported by the project, which has received funding from the Malaysian Government under the Long Run Grant Scheme (LRGS) (LR001B-2016A).
} 


\section{ENTREPRENEURSHIP AND SUSTAINABILITY ISSUES}

ISSN 2345-0282 (online) http://jssidoi.org/jesi/

2020 Volume 8 Number 1 (September)

http://doi.org/10.9770/jesi.2020.8.1(73)

\section{Introduction}

Light emitting diode (LED), which is made from semiconductor chip represents one of the important technological revolutions in the lighting industry, which support the sustainable development goals (SDG). The LED consumes lesser energy, does not emit high heat loss and is made from recyclable materials, which can be dismantled and reused. Since LED could last more than 20 years, it requires lesser replacement, which leads to lesser use of natural resources. Considering the characteristics of LED, it is therefore, not surprising that many governments around the world have started to use LEDs, as an alternative (Khorasanizadeh, Parkkinen, Parthiban, Moore 2015), leading to its growing market demands. As reported by Mordor Intelligence (2019), the growth of the LED industry globally has reached USD 51.8 billion, and is expected to climb to USD 112.15 billion by 2024, with major portions generated by Asian countries. Within the Asian continent, China appears to be the dominant player in the LED value chains. As the country possess rare-elements resources required in the production of LED, their local manufacturers are able to compete aggresively in the global market, by offering cheaper products (Levy, Meisner Rosen, Iles 2017). This situation creates a challenge to the neighbouring countries, including Malaysia, calling them to configure their operations strategy. To survive, the Malaysian local manufacturers could not be the "follower", by offering the "me too" products, since they will be trapped in the crowded market and quick declined of the price of final goods. Hence, for a local manufacturer to stay afloat, it is assumed that innovation is important. This element is not only being associated with new product development and enhancement, but also related to process improvement, which in turn could help reducing operational costs (Kim, Chai 2017; Vargas 2015).

Whilst being innovative is seen as pertinent to sustain competitiveness, yet, in order to be innovative, firms need to know how the innovation process works. Within the literature, early works on innovation process seems to emphasise on the research and development (R \& D) activities and market pull-view as means to support innovation (e.g. Pavitt, Robson, Townsend 1989; De Luca, Verona, Vicari 2010). Despite this, the relationships are argued to be influenced by various other factors; and are not linear (Anning-Dorson 2016). In a simplest word, an increased on a firm's financial allocation on R \& D may not assure proportional growth in returns. Additionally, merely responding to the market alone, may not results in path-breaking innovations, which are important in the technological industry, such as LED. As firms are moving towards global competitiveness, they need to look beyond their organisational boundaries; and identify as well as evaluate how the resources and capabilities of their supply chain partners can be optimised to create exceptional values (Kim, Chai 2017; Zimmermann, Ferreira, Carrizo Moreira 2016). These processes are driven by dynamic entrepreneurs, who are known as a risk bearer, innovator and opportunist (Schumpeter 2017).

Built upon these arguments, this study attempts to investigate how four LED manufacturers in Malaysia build their innovative capabilities through dynamic entrepreneurs. It seeks to explore how dynamic entrepreneurships promote supply chain collaboration and innovative capabilities in the organisations, based on the dynamic capabilities theory. This study will contribute to the limited literature that attempted to explore this phenomenon by looking at the dynamic entrepreneurs. In this study, we also focused on Malaysian as the contextual setting. As a middle-income nation, Malaysia appears to stuck in the middle, whereby they are unable to compete with lowwage nations, yet at the same time not being able to enhance the skills and knowledge required for higher value added production and services. Dominated by multi-national firms which having lack of public interest for the betterment of education has led to the slow improvement in meeting the demands of highly skilled workforce (Doner, Schneider 2016). Literature seems to emphasise that in this kind of country context, dynamic entrepreneurs play important role for private sector development, in which they have promoted innovative culture of many Asian countries. This in turn helps them to surpass their middle-income status. 


\section{ENTREPRENEURSHIP AND SUSTAINABILITY ISSUES}

ISSN 2345-0282 (online) http://jssidoi.org/jesi/

2020 Volume 8 Number 1 (September)

http://doi.org/10.9770/jesi.2020.8.1(73)

\section{Literature Review}

\subsection{Innovations}

Innovation is referred to a process of generating new ideas, processes or products that could add values to the customers as well as the organisations (Druehl, Carrillo Hsuan 2018). It is well recognised that the ability of an organisation to innovate help firms to grow and survive, particularly in the era of globalisation. For contract manufacturers, especially those in the key manufacturing sectors such as electronics and automotive, innovation appears to be the indicator of their ability to respond to the increasing demands from customers (Song, Fang, Johnston 2017). This is because innovation is expected to facilitate value analysis and value engineering approaches, which drive new product development.

Whilst various literature seems to emphasise the importance of innovation in sustaining an organisation's competitiveness (e.g. Kiveu, Namusonge, Muathe 2019; Coad, Grassano, Hall, Moncada-Paternò-Castello, Vezzani, 2019), innovation does not always lead to success. In fact, it is risky, involve uncertain process and consume huge resources. Often time, innovation failed due to the heavily relying on $\mathrm{R} \& \mathrm{D}$ team in generating ideas, or new products/process, and producing "me-too" products/services (De Luca, Verona, Vicari 2010). There are also organisations which tend to resist ideas from external parties, and focus more on "internally generated ideas" (Camisón et al. 2016). For these organisations, they are often trapped in obsolete technology, fail to see the market trends, and take a long-time to introduce new products/process to the markets. These literature indicate that partial views of what innovation process involved will results in an organisation producing products/services which are not only fails to meet users' needs and expectations, but also fails to generate internal knowledge, resources and capabilities.

\subsection{Dynamic Capability Theory}

Teece (2018) argued that for an organisation to achieve competitive advantage, it needs to demonstrate the dynamic capabilities, which could be referred to an organisation's ability to build and reconfigure internal as well as external competencies to survive in the turbulent environments. It is associated with organisations' learned patterns of collective activity and strategic routines, through which operating practices are modified to achieve a new configuration. In the era of globalisation, organisations may face higher chances of supply chain disruptions due to the market conditions which are more prone to uncertainties, due to varying institutions, cultures, market, demand requirements and political and socio-economic realities (Weerawardena, Mort, Liesch, Knight 2007). This situation requires them to be responsive by sensing new threats or opportunities emerging in the environment, and reconfiguring and realigning their resources as a means to alleviate the risks and rebound to the original position. In this condition, static resources may not be able to generate favourable organisational performance. This suggests that organisations need to continuously develop new capabilities to ensure that the processes, skills and routines are attuned with the changing needs. Various studies in the area of strategic management have adapted this theory. They include Madanmohan, Kumar, Kumar (2004), Rashid, Jabar, Yahya, Samer (2015) and Albino, Dangelico, Pontrandolfo (2012). Their studies illustrate that having a dynamic entrepreneur could help gain benefits from the supply collaboration which has led to dynamic capabilities and performance.

Dynamic entrepreneurs refer to the ability of a company's leader to discover, creates, seize and exploit opportunities ahead of their rivals (Kuratko, Hornsby, Hayton 2015). It exists in organisations where leaders and the culture works together to generate impetus to innovate, take risks and pursue new opportunities (Dess Lumpkin, 2005; Hsu, Tan, Jayaram, Laosirihongthong 2014). In an organisation with a high dynamic entrepreneurship, the leader acts as a gatekeeper, and always finds ways of how to optimise internal resources to attain success (Eggers, Kraus, Hughes, Laraway, Snycerski, 2013). A corporate leader who exhibits dynamic entrepreneurial behaviour tends to create a work environments and corporate culture that stimulate and support 


\section{ENTREPRENEURSHIP AND SUSTAINABILITY ISSUES}

ISSN 2345-0282 (online) http://jssidoi.org/jesi/ 2020 Volume 8 Number 1 (September) http://doi.org/10.9770/jesi.2020.8.1(73)

creativity. It is widely recognised that the keys impacting innovation successfulness are resources. One perspective to obtain resources for innovation has been to incorporate the supply chain collaboration strategy with innovation process (Simatupang, Sridharan 2008). In a collaborative supply chain, organisations involved share resources and capabilities to create synergy and meet their customers' needs. They use their core competencies to handle change and deal with adaptive challenges (Soosay, Hyland, Ferrer 2008). The role of supply chain collaboration in innovation process is becoming crucial owing to the growing outsourcing practices (Gereffi, Lee, 2012). This is particularly true for those that are coming from emerging market. On one hand, these organisations commonly lack of financial and technological capabilities for innovation projects. On the other hand, the innovation process consumes substantial amount of financial resources since funds are needed not only to develop new products or processes, but to also offer training, user-support and marketing campaign explaining the merits of innovation. Hence, to support the success of their innovation, they collaborate with key supply chain partners. Through inter-organisational linkages, they could obtain access to related resources and capabilities that are difficult to create on their own (Zimmermann, Ferreira, Carrizo Moreira 2016).

\section{Research Methodology}

This study employed semi-structured interviews to investigate how the organisations use dynamic entrepreneurship to develop innovative capabilities. This method carries more weight as it can give powerful and detailed insights, since it could elicit the respondents' views and experiences as compared to surveys (Chetty, 1996; Yin 2003). To supplement the information obtained from the interviews, internal reports and documents were also reviewed. Prior to the interview sessions, the questions asked were assessed and evaluated by an independent Malaysian researcher who majors in supply chain strategy.

The sampling frame for this study was drawn from the list of LED manufacturers registered with the Federation of Malaysian Manufacturers as of August 2018. The total number of registered manufacturers was 241. This study selected every tenth manufacturers from the list provided. They were initially contacted through telephone calls to determine that they have performed innovation activities and shown dynamic entrepreneurship behaviours. This is to ensure that the samples selected are appropriate and have experiences in the area of study. Of the 24 manufacturers contacted, only four of them were found to satisfy the above conditions, and willing to participate in the study. During this initial contact, emphasis was also made to indicate that the data collected would be exclusively used for research purposes only and that the manufacturers' participation would be kept private and confidential. Anonymity was applied and so their voluntariness to participate in the study served as their consent for participation. They were also given opportunities to discontinue their participation at any point of the study should the need arises. The distribution of the respondents interviewed within the four companies is shown in Table 1. A total of 17 respondents were interviewed, and were considered appropriate, as in line with Guest, Bunce, Johnson (2006). As indicated by the table, the respondents seem to have various roles with different levels and functions in the respective organisation. To ensure the quality and validity of the responses gathered, the managers interviewed were asked to verify the interview reports.

Table 1. Respondents' Profiles

\begin{tabular}{|c|c|c|c|c|}
\hline Company & Respondents & Years of Establishment & Position/Level & Functions \\
\hline \multirow[t]{4}{*}{$\mathrm{A}$} & 1 & \multirow[t]{4}{*}{19} & Manager & Product Design \& Development \\
\hline & 2 & & Manager & Technical Specialist \\
\hline & 3 & & Senior manager & Research \& Development \\
\hline & 4 & & Manager & Operations \\
\hline \multirow[t]{4}{*}{ B } & 5 & \multirow[t]{4}{*}{16} & Manager & Supply Chain \\
\hline & 6 & & Senior Manager & Product Design \& Development \\
\hline & 7 & & Manager & Procurement \\
\hline & 8 & & Manager & Project Management \\
\hline $\mathrm{C}$ & 9 & 21 & Manager & Procurement \\
\hline
\end{tabular}


ENTREPRENEURSHIP AND SUSTAINABILITY ISSUES

ISSN 2345-0282 (online) http://jssidoi.org/jesi/ 2020 Volume 8 Number 1 (September) http://doi.org/10.9770/jesi.2020.8.1(73)

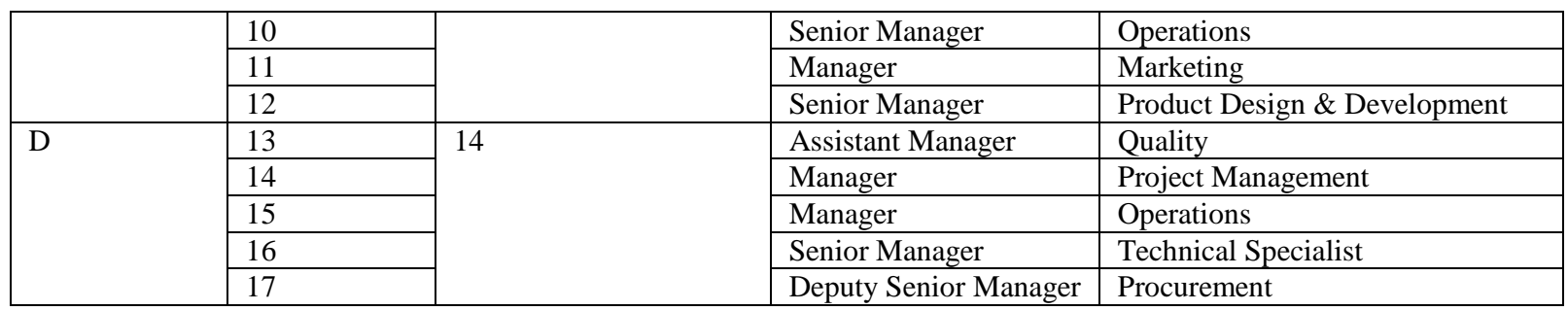

A semi structured interview was conducted during the last week of August 2018 and the first week of November. Each interview session last for 20 to 40 minutes, with the main focus to draw the interviewees to comment and describe how corporate entrepreneurship and supply chain integration were practiced in their organisations. The samples of questions asked were provided in the Appendix 1. All the interviews were conducted in English and recorded using a voice recorder. Following the interviews, data were listed accordingly and then placed into respective envelopes for easy identification. This was then followed by the transcribing process where the recorded interviews were played several times until the entire interview was completely transcribed. In the analysis stage, the organised materials were read line-by-line several times. The content of each interview were then further analysed so as to gain a deeper descriptive structure of the responses. The relevant quotes from the transcript were marked and coded accordingly. The quotes identified were contrasted with each other to provide a more balanced view of the contribution of each participant. This process was conducted continuously through several repetitions until there was no significant insight that could be obtained from the analysis.

\section{Research Findings}

Analysis of the response related to how dynamic entrepreneurship affects innovative capabilities is detailed in Table 2. The following sections discuss the findings further.

Table 2. Research Findings

\begin{tabular}{|c|c|c|c|c|c|c|c|c|c|c|c|c|c|c|c|c|c|c|}
\hline \multirow{2}{*}{ Categories } & \multirow[t]{2}{*}{ Sub-Categories } & \multicolumn{17}{|c|}{ Respondents } \\
\hline & & 1 & 2 & 3 & 4 & 5 & 6 & 7 & 8 & 9 & 10 & 11 & 12 & 13 & 14 & 15 & 16 & 17 \\
\hline \multirow[t]{10}{*}{$\begin{array}{l}\text { Dynamic } \\
\text { Entrepreneurship }\end{array}$} & $\begin{array}{l}\text { Entreprenurial attitudes } \\
\text { and enthusiasm }\end{array}$ & I & I & I & I & & & & & I & I & I & I & & & & & \\
\hline & $\begin{array}{l}\text { Corporate culture and } \\
\text { empowerment }\end{array}$ & l & I & I & I & I & I & I & I & I & I & I & I & I & I & I & I & I \\
\hline & Cross functional teams & I & 1 & 1 & 1 & I & 1 & I & I & I & I & 1 & I & I & I & I & I & I \\
\hline & Customer integration & 1 & 1 & 1 & 1 & I & 1 & 1 & 1 & & & & & 1 & I & I & I & I \\
\hline & Supplier integration & 1 & 1 & 1 & 1 & 1 & 1 & 1 & 1 & 1 & 1 & 1 & 1 & & & & & \\
\hline & Communication & I & I & I & I & I & I & I & I & I & I & I & I & I & I & I & I & I \\
\hline & Trust & I & I & I & 1 & & & & & I & I & 1 & I & I & I & I & I & I \\
\hline & Relationship & 1 & 1 & 1 & 1 & 1 & 1 & 1 & 1 & 1 & 1 & 1 & 1 & 1 & 1 & 1 & 1 & 1 \\
\hline & Resource sharing & & & & & 1 & 1 & 1 & 1 & & & & & 1 & I & I & I & I \\
\hline & $\begin{array}{l}\text { Information knowledge } \\
\text { sharing }\end{array}$ & I & I & I & I & I & I & I & I & I & I & I & I & I & I & I & I & I \\
\hline
\end{tabular}

Company A was established by two founders for about 20 years ago, who had previously worked at multinational firms in the technological industry. Their career change decision came from their own intrinsic motivation to be entrepreneurs. After seven difficult years, the company has started to grow every year, and now is not only become the "follower", but also strives to offer innovative solutions. One of the company's senior managers, Mr. $\mathrm{X}$, stated that: 


\section{ENTREPRENEURSHIP AND SUSTAINABILITY ISSUES}

ISSN 2345-0282 (online) http://jssidoi.org/jesi/

2020 Volume 8 Number 1 (September)

http://doi.org/10.9770/jesi.2020.8.1(73)

"We are always looking for new opportunities. It is very important to be able to see new trends and opportunities if we want to survive for a long-time. We cannot always provide products at cheaper price, because the market can get saturated.... we have to move fast, see how we can use and configure our resources. What can we make from what we have is very important"

[Respondent 3]

This shows that Company's A manager possess entrepreneurial attitude towards innovation. The leader or the head of department demonstrates the importance of continuous search of opportunities. He is always looking for more effective innovative procedures to carry out new product development or process improvement. This is also supported by the employees interviewed, who mentioned:

"Both the founders of this company keep on looking for new things every day. For now, they are interested in the area of sensors, smart devices, IoT and automotive sectors. They see these areas as the new industry that they could focus to spearhead the growth of LEDs"

[Respondent 2]

"The top management, especially our chief executive officer (CEO) is always looking for improvement, and new ways of doing certain things, although it's only a small improvement. He always pushing the business all the time. ..we strive for 15 per cent of growth every year"

[Respondent 11]

The leaders' enthusiasm on innovation has also been translated into the culture of the organisations. In Company D for example, the management, either at the strategic or operational levels are encouraging their sub-ordinates to generate ideas by enforcing "no-criticism rule", although the ideas provided sometimes, could be wild and seem to be impractical. As indicated by one of the respondents from Company D:

“... at our unit, we are invited to make any suggestions. Any proposal or ideas put forwarded, are collected and processed by our head or sometime project leader... when we are working in a group... although these ideas are sometimes seem to be "small", "minor", "unimportant", they are being recognised by our top management... we get rewarded when we suggest something."

[Respondent 17]

At company B, it is found that the aim of empowerment is not seen as a means to tackle problems, but it could also encourage personal development, as every individual in the organisation can exercise creativity. The respondent highlighted that:

"Empowerment help spread out the problem solving activity across the organisational boundaries. We can understand, share and learn from each other"

[Respondent 6]

In this study, we found that all organisations studied used cross-functional teams to promote creativity. The respondents from Company A reported that:

"New product-development process in our company is smoother now as compared to before. With the use of cross-functional team, we can now expect and know the effect of changing 


\section{ENTREPRENEURSHIP AND SUSTAINABILITY ISSUES}

ISSN 2345-0282 (online) http://jssidoi.org/jesi/

2020 Volume 8 Number 1 (September)

http://doi.org/10.9770/jesi.2020.8.1(73)

certain process on other departments or functions performed by other...not like before, we used to spend lot of time working on something, and then find out the idea doesn't pan out. With the use of groups, we can know whether the idea is possible or not immediately, rather than to do it and then down the road, it's not feasible to do"

[Respondent 2]

"We normally work in a team to develop products. We can compare, communicate the products that we are developing more effectively. Sometimes, we can even identify whether the various products will sit together as a complete product range. Similarly, the products that do not sell well in the market can also be communicated easily to production team, so that those product lines can be stopped or reduced, and replace with another that sell well. This helps in speeding up replenishment times and reducing inventory"

[Respondent 3]

At Company $\mathrm{C}$, it was highlighted that they have reconfigured their purchasing process, by centralising the function. In the new process, the purchasing activities are conducted collaboratively between the purchasing team and product development team. This practice helps ensuring successful innovation process, in which it enables the company to control exposure to supply chain risks due to failed product design. As indicated by the respondents from Company C:

"We used to leave the process [buying the materials] with the individual managers involved. But we ended up with huge supplier base and unattractive product range...this process has been made better when they [i.e. the purchasing department and product development teams] work together. We have to take this direction, considering that product design is our core value"

[Respondent 9]

In this study, we found that all organisations perceived design capabilities as the main source of their innovativeness. This function is found to be handled by not only the New Product Development (NPD) teams, but also the companies' supply chain partners. This practice is seen to help them ensuring the product commercialisation and coordination.

At Company A, the managers interviewed highlighted that the company co-innovate with its customers, rather than performing it on their own. According to them:

"We are currently working with our US based customers in developing laser LED car headlamps. Previously, we used to work together with them in coming up with brighter LED module... we are also exploring how to combine semiconductor lighting with new technologies such as smart sensors and wearable technologies... at our company, we are encourage by the top management to work together with our partners... although it seems to be difficult, after several years now, we can see our company's direction."

[Respondent 2]

“...We have depended on our $R \& D$ experiences of producing dies for LED components when we move to produce LED components. Yet, over times, $R \& D$ experiences alone may not work. That's become the reason, why we are embarking on joint effort. Sometimes, we are not able to see the trends, the market when we work alone... So, yes, we are depending on our customers as well when we embrace on new project... willingness to share 


\section{ENTREPRENEURSHIP AND SUSTAINABILITY ISSUES}

ISSN 2345-0282 (online) http://jssidoi.org/jesi/

2020 Volume 8 Number 1 (September)

http://doi.org/10.9770/jesi.2020.8.1(73)

knowledge, resources and exploring new things are all that matters in this collabortion. Our leaders keep on insisting that we should work together, and need to be able to reap all the benefits that we could obtained from this partnership. "

[Respondent 3]

The integration between Company A and its customers also seem to improve its abilities to satisfy the customers' needs better. The respondent indicated that:

"...we can now give our customer what they want...when we break the barriers between our firm and customers, we can share information with them more accurately. Before this, everything was done based on the prediction, and not actual data. By setting up jointventure between the company and customers, we can openly discussed what will work, what won't work, and develop solutions together"

[Respondent 1]

Similarly, Company B also demonstrated the same experiences. At Company B, however, the integration occurs between the company and its key suppliers. As stated by the respondents:

“...we are struggling in today's environment. The technology moves very fast, and there is no way we could keep up with the market, if we don't work together with our key suppliers... working with them [immediate suppliers] help improving designs... what is more important is, by forming such relationship, we can access to the external resources."

[Respondent 5]

'During the start-up period, we suffered a lot, we don't have the right materials, and we even have problems with our previous suppliers back then. But, when we start to integrate with suppliers... it's getting better...we tend to be more relaxed, we believe our suppliers are reliable. But of course, before we could reach to that point, we have to screen our existing suppliers, identify those who are important to our business..."

[Respondent 6]

“...we also source from local suppliers, and they sometime do not possess capabilities. So, what we do, we intervene with their process, assist them in developing certain skills. We invest in providing quality management training courses to help improve their process. And in return, the supplier offer advices and expertise in the design of LED components.

[Respondent 6]

This shows that in today's environment, where technology is rapidly changing, companies sustain themselves by nurturing innovations and creativity through collaborating with suppliers. Although the supply chain collaboration does help the companies interviewed in nurturing their innovativeness, it is found that such practice is not without hurdles. For example, one of the respondents highlighted that:

“...individualistic, competitive and lack of communication and information visibility may not support innovation culture. We for example, need to know what the end-customers are buying, how well the products produced are accepted and etc...this information will help us in coming up with the new products that will be well-accepted in the market"

[Respondent 15] 


\section{ENTREPRENEURSHIP AND SUSTAINABILITY ISSUES}

ISSN 2345-0282 (online) http://jssidoi.org/jesi/

2020 Volume 8 Number 1 (September)

http://doi.org/10.9770/jesi.2020.8.1(73)

Notwithstanding these, the respondents also indicated that in order to successfully implementing a supply chain integration practice, that will benefit the organisations in terms of innovativeness, they have to forgo their silo mentality and nurture trusts. The respondents from both companies stated that:

“...before we proceed with building electronic infrastructure to facilitate information sharing with our customers, we ensure that we have a good relationship. We need to assure that our partners can be trusted. This is important as we do not want to invest our resources, and then further down the road, find that our partners are not behaved as what we expected."

[Respondent 11]

“...committing resources for integration can consume a lot... there is a need for us to build a good and long-term relationship in order for it to be successful. The switching cost could also be higher, if we invest, without having good relationship..."

[Respondent 12]

“... a close relationship with customers facilitate us in sharing knowledge about consumer preferences and desired product features. This will help us to enhance our innovative capabilities and develop new products..."

[Respondent 2]

\section{Discussion}

Considering the rapid development of the LED industry, and technology/knowledge intensive firms in emerging markets, such as Malaysia, the case studies evaluate how a manufacturer is likely to survive in the globalisation era through innovation.

In examining how the companies develop their innovation and creativity through dynamic entrepreneurship, three points stand out. First, the cases highlighted the importance of having a leader, manager or owner who has dynamic entrepreneurial orientation. As highlighted by the cases studied, the founders' abilities to identify opportunities arisen, and transform them into business activities will drive the company's innovative capabilities. In this type of organisation, the leaders are found to willingly support creativity and experimentation. They encourage their employees to "think out of box", and are more open to any ideas generated. By promoting this organisational culture, employees feel more empowered to try out new practice based on their own initiative. In relating to this, it seems that the employees trained in MNC affiliates could become the seed bed for the emergence of home-grown companies. As indicated in the case, Company A's founders appear to have worked with the MNCs before, which have provided them ample experiences and related training. Having leaders who have worked in the MNCs facilitate the companies to drive the strategic innovations better in which they extract creative ideas from market insights and promote them within the company, provide support and access to resources. These findings are found to be inline with prior works by Tan (2006) and Inkpen, Tsang (2005).

Secondly, in this study, we found that a dynamic entrepreneur often encourage the use of cross-functional teams, where individuals from different departments work together. With this approach, it appears that everyone in the organisations is learning from other prior experiences, and seeking out opportunities to learn, and self-developed. This practice will also help people across the organisations to understand and share the holistic view of processes in the company. As demonstrated by Company A, people in the organisation works together in finding ways of how the production costs could be reduced by altering the design. They can even identify if products across all sections will sit together as a complete product ranges offered by the manufacturing firm. In the case of Company $\mathrm{B}$, the product development team's responsibility is also found not to be restricted on the product design process per se, but the team is also linked to the purchasing process, where they could make final decision on the product specifications that should be supplied by the suppliers. The case demonstrates that by allowing the team to be part of the final purchasing decision, the company is able to reduce supply chain risks due to failed product design. 


\section{ENTREPRENEURSHIP AND SUSTAINABILITY ISSUES}

ISSN 2345-0282 (online) http://jssidoi.org/jesi/ 2020 Volume 8 Number 1 (September) http://doi.org/10.9770/jesi.2020.8.1(73)

The linkage of various departments goes beyond the problem solving. Infact, the use of teamwork facilitates in sharing and exchanging ideas, and breaking down communication barriers among divisions. This approach also seems to support open-ended learning behaviour in the organisation, which is expected to lead to creativity and innovative capabilities. This is expected since in a high-technology business environment, high levels of collaboration and teamwork are important, whereby many innovations were carried out by a "teams of experts" rather than "lone hero" (Di Benedetto, Calantone, VanAllen, Montoya-Weiss 2003).

Third, the cases examined highlights that the coordination and collaboration that are practiced under the dynamic entrepreneurship are not only limited within the organisation. In fact, they go beyond the organisational boundaries. From the cases studied, it is safely to say that an entrepreneur needs to be able to identify opportunities that arise from the external parties, in this case the supply chain partners. Being a medium size companies, they are notably lack of internal resources to embrace on innovations. Instead, they have to coinnovate with their supply chain partners, whereby they share knowledge and technology (Welbourne, Pardo-delVal 2009). As demonstrated by the findings, the shortage of funds to seek for differentiation strategy has forced the entrepreneurs to jointly invest with its customers to develop new range of LED chips, three-dimensional imaging modules and multi-port sensors. With supply chain collaboration, they have also ventured into other areas that are based on LED technology. They have gradually explored the future direction of the industry, specifically in the area of smart sensors and wearable technology, through working cooperatively with its customers. In maintaining the effectiveness of the collaborative efforts, it was found that the entrepreneurs are willing to share information and knowledge with their customers and suppliers. The extent of their willingness to openly shares information and knowledge can facilitate new product development.

\section{Implications and Conclusion}

This study has focused on how the local manufacturing firms in the LED industry build up their innovative capabilities through dynamic entrepreneurship. The findings of this study contribute to the limited literature exist to explain how dynamic entrepreneurship stimulate innovativeness from the emerging country's perspective, specifically Malaysia.

The findings of this study suggest that in the context of developing countries, such as Malaysia, dynamic entrepreneurship appears to encourage innovative capabilities. Of particular interests are, the role of top management or leaders of the companies in motivating and shaping entrepreneurial behaviours in organisations. In order for the employees to be creative and innovative, the managers need to create an environment that promotes freedom to experiment without fear of reprisal, when initiatives taken do not lead to desired results. Although basic knowledge in science and technical competences may seem to be fundamental to technological industry, yet, when it comes to innovation, basic knowledge and skills are insufficient. The employees need to be creative; and the creativity can only be unleashed in an organisational environment that promotes freedom of thinking and self-direction.

The findings of this study also reinforced the importance of dynamic capabilities towards supply chain collaboration. The leaders of the local companies need to be able to identify and reap the opportunities arise from the collaboration practice with the supply chain partners. As demonstrated by the cases, the abilities of the entrepreneurs in working together effectively with their supply chain partners in designing new products or enhancing existing processes, have offered opportunities for them to venture into markets that have not been explored before. This is because, through having dynamic entrepreneurships, they are able to reconfigure their internal as well as external resources and create synergies in the collaborative practice. This is particularly true for those manufacturing firms that are found to be small, as they are notably lack in resources to move forward. 


\section{ENTREPRENEURSHIP AND SUSTAINABILITY ISSUES}

ISSN 2345-0282 (online) http://jssidoi.org/jesi/ 2020 Volume 8 Number 1 (September) http://doi.org/10.9770/jesi.2020.8.1(73)

Whilst it is conventionally argued that the innovative capabilities of manufacturers in emerging countries tend to be heavily supported by favourable institutional policy, the case studied suggests that the home-grown company can also survive by relying on its internal resources. Driven by internal capabilities such as dynamic entrepreneurship, they are able to develop innovative capabilities, and sustain their competitiveness. In a competitive environment, a manufacturer needs to differentiate their internal capabilities from competitors to achieve competitive advantage. This case study demonstrates that manufacturers can remain competitive when they align human resource management with technological innovation; develop internal organisational culture, work processes and activities that promote creativity.

\section{References}

Albino, V., Dangelico, R. M., \& Pontrandolfo, P. (2012). Do inter-organizational collaborations enhance a firm's environmental performance? A study of the largest US companies. Journal of Cleaner Production, 37, 304-315. http://dx.doi.org/10.1016/j.jclepro.2012.07.033

Anning-Dorson, T. (2016). Organisational culture and leadership as mediators of service innovation and firm competitiveness: a study of an emerging economy. International Journal of Innovation Management, 20(7), 165-206. http://dx.doi.org/10.1142/S136391961650064X

Di Benedetto, C. A., Calantone, R. J., VanAllen, E., \& Montoya-Weiss, M. M. (2003). Purchasing joins the NPD team. ResearchTechnology Management, 46(4), 45-51. http://dx.doi.org/10.1080/08956308.2003.11671576

Camisón, C., Puig-Denia, A., Forés, B., Fabra, M. E., Muñoz, A., \& Munoz Martinez, C. (2016). The importance of internal resources and capabilities and destination resources to explain firm competitive position in the Spanish tourism industry. International Journal of Tourism Research, 18(4), 341-356. http://dx.doi.org/10.1002/jtr.2053

Coad, A., Grassano, N., Hall, B. H., Moncada-Paternò-Castello, P., \& Vezzani, A. (2019). Innovation and industrial dynamics. Structural Change and Economic Dynamics, 50, 126-131. http://dx.doi.org/10.1016/j.strueco.2019.06.008

Chetty, S. (1996). The case study method for research in small-and medium-sized firms. International Small Business Journal, 15(1), 7385. http://dx.doi.org/10.1177/0266242696151005

De Luca, L. M., Verona, G., \& Vicari, S. (2010). Market orientation and R\&D effectiveness in High-Technology firms: An empirical investigation in the biotechnology industry. Journal of Product Innovation Management, 27(3), 299-320. http://dx.doi.org/10.1111/j.1540$\underline{5885.2010 .00718 . x}$

Dess, G. G., \& Lumpkin, G. T. (2005). The role of entrepreneurial orientation in stimulating effective corporate entrepreneurship. Academy of Management Perspectives, 19(1), 147-156. http://dx.doi.org/10.5465/AME.2005.15841975

Doner, R. F., \& Schneider, B. R. (2016). The middle-income trap: more politics than economics. World Politics, 68(4), 608-644. http://dx.doi.org/10.1017/S0043887116000095

Druehl, C., Carrillo, J., \& Hsuan, J. (2018). Technological Innovations: Impacts on Supply Chains. In A.M., Moreira, Luís Miguel, D. F. , \& Zimmermann, F. Innovation and Supply Chain Management (pp. 259-281). Springer: Cham.

Eggers, F., Kraus, S., Hughes, M., Laraway, S., \& Snycerski, S. (2013). Implications of customer and entrepreneurial orientations for SME growth. Management Decision, 51(3), 524-546. http://dx.doi.org/10.1108/002517411311309643

Gereffi, G., \& Lee, J. (2012). Why the world suddenly cares about global supply chains. Journal of Supply Chain Management, 48(3), 2432. http://dx.doi.org/10.1111/j.1745-493X.2012.03271.x

Guest, G., Bunce, A., \& Johnson, L. (2006). How many interviews are enough? An experiment with data saturation and variability. Field Methods, 18(1), 59-82. http://dx.doi.org/10.1177/1525822X05279903

Hall, K. L., Feng, A. X., Moser, R. P., Stokols, D., \& Taylor, B. K. (2008). Moving the science of team science forward: collaboration and creativity. American Journal of Preventive Medicine, 35(2), S243-S249. http://dx.doi.org/10.1016/j.amepre.2008.05.007 


\section{ENTREPRENEURSHIP AND SUSTAINABILITY ISSUES}

ISSN 2345-0282 (online) http://jssidoi.org/jesi/ 2020 Volume 8 Number 1 (September)

http://doi.org/10.9770/jesi.2020.8.1(73)

Hsu, C. C., Tan, K. C., Jayaram, J., \& Laosirihongthong, T. (2014). Corporate entrepreneurship, operations core competency and innovation in emerging economies. International Journal of Production Research, 52(18), 5467-5483.

http://dx.doi.org/10.1080/00207543.2014.915069

Inkpen, A. C., \& Wang, P. 2006. An examination of collaboration and knowledge transfer: China-Singapore Suzhou Industrial Park. Journal of Management Studies, 43(4): 779-811. http://dx.doi.org/10.1111/j.1467-6486.2006.00611.x

Khorasanizadeh, H., Parkkinen, J., Parthiban, R., \& Moore, J. D. (2015). Energy and economic benefits of LED adoption in Malaysia. Renewable and Sustainable Energy Reviews, 49, 629-637. http://dx.doi.org/10.1016/j.rser.2015.04.112

Kim, M., \& Chai, S. (2017). The impact of supplier innovativeness, information sharing and strategic sourcing on improving supply chain agility: Global supply chain perspective. International Journal of Production Economics, 187, 42-52.

http://dx.doi.org/10.1016/j.ijpe.2017.02.007

Kiveu, M. N., Namusonge, M., \& Muathe, S. (2019). Effect of innovation on firm competitiveness: the case of manufacturing SMEs in Nairobi County, Kenya. International Journal of Business Innovation and Research, 18(3), 307-327. http://dx.doi.org/10.1504/IJBIR.2019.098251

Kuratko, D. F., Hornsby, J. S., \& Hayton, J. (2015). Corporate entrepreneurship: the innovative challenge for a new global economic reality. Small Business Economics, 45(2), 245-253. http://dx.doi.org/10.1007/s11187-015-9630-8

Levy, S., Meisner Rosen, C., \& Iles, A. (2017). Mapping the Product Life Cycle: Rare Earth Elements in Electronics. Case Studies in the Environment, 1-9. http://dx.doi.org/10.1525/cse.2017.000265

Madanmohan, T. R., Kumar, U., \& Kumar, V. (2004). Import-led technological capability: a comparative analysis of Indian and Indonesian manufacturing firms. Technovation, 24(12), 979-993. http://dx.doi.org/10.1016/S0166-4972(03)00030-0

Mordor Intelligence (2019). LED Lighting Market - Growth, Trends, and Forecast (2019 - 2024). Retrieved from https://www.mordorintelligence.com/industry-reports/led-lighting-market

Pavitt, K., Robson, M. and Townsend, J. (1989) Technological accumulation, diversification and organization in U.K. Companies 19451983. Management Science, 35, 81-99. http://dx.doi.org/10.1287/mnsc.35.1.81

Rashid, N., Jabar, J., Yahya, S., \& Samer, S. (2015). State of the Art of Sustainable Development: An Empirical Evidence from Firm's Resource and Capabilities of Malaysian Automotive Industry. Procedia-Social and Behavioral Sciences, 195, 463-472. http://dx.doi.org/10.1016/j.sbspro.2015.06.488

Schumpeter, J. A. (2017). Essays: On entrepreneurs, innovations, business cycles and the evolution of capitalism. Thousand Oaks, California: Routledge.

Simatupang, T. M., \& Sridharan, R. (2008). Design for supply chain collaboration. Business Process Management Journal, 14(3), 401-418. http://dx.doi.org/10.1108/14637150810876698

Song, L., Fang, C., \& Johnston, L. (2017). China's path towards new growth: Drivers of human capital, innovation and technological change. Australian National University Press: Australia.

Soosay, C. A., Hyland, P. W., \& Ferrer, M. (2008). Supply chain collaboration: Capabilities for continuous innovation. Supply Chain Management: An International Journal, 13(2), 160-169. http://dx.doi.org/10.1108/13598540810860994

Tan, J. 2006. Growth of industry clusters and innovation: Lessons from Beijing Zhongguancun Science Park. Journal of Business Venturing, 21(6), 827-850. http://dx.doi.org/10.1016/j.jbusvent.2005.06.006

Teece, D. J. (2018). Business models and dynamic capabilities. Long Range Planning, 51(1), 40-49. http://dx.doi.org/10.1016/j.lrp.2017.06.007

Vargas, M. I. R. (2015). Determinant factors for small business to achieve innovation, high performance and competitiveness: organizational learning and leadership style. Procedia-Social and Behavioral Sciences, 169, 43-52. http://dx.doi.org/10.1016/j.sbspro.2015.01.284 


\section{ENTREPRENEURSHIP AND SUSTAINABILITY ISSUES}

ISSN 2345-0282 (online) http://jssidoi.org/jesi/ 2020 Volume 8 Number 1 (September) http://doi.org/10.9770/jesi.2020.8.1(73)

Wang, P., Rode, J. C., Shi, K., Luo, Z., \& Chen, W. (2013). A workgroup climate perspective on the relationships among transformational leadership, workgroup diversity, and employee creativity. Group \& Organization Management, 38(3), 334-360. http://dx.doi.org/10.1177/1059601113488163

Weerawardena, J., Mort, G. S., Liesch, P. W., \& Knight, G. (2007). Conceptualizing accelerated internationalization in the born global firm: A dynamic capabilities perspective. Journal of World Business, 42(3), 294-306. http://dx.doi.org/10.1016/j.jwb.2007.04.004

Welbourne, T. M., \& Pardo-del-Val, M. (2009). Relational capital: strategic advantage for small and medium-size enterprises (SMEs) through negotiation and collaboration. Group Decision and Negotiation, 18(5), 483-497. http://dx.doi.org/10.1007/s10726-008-9138-6

Yin, R. (2003).). Case study research: Design and methods. Thousand Oaks, California: Sage Publications.

Zimmermann, R., Ferreira, L. M., \& Carrizo Moreira, A. (2016). The influence of supply chain on the innovation process: a systematic literature review. Supply Chain Management: An International Journal, 21(3), 289-304. http://dx.doi.org/10.1108/SCM-07-2015-0266

\section{Acknowledgements}

This research was supported by the project, which has received funding from the Malaysian Government under the Long Run Grant Scheme (LRGS) (LR001B-2016A).

Suhana MOHEZAR is a Associate Professor at the University of Malaya. She obtained a PhD in operations management from the University of South Australia. Her research interests include value chain management, innovations, and disruptive technology.

ORCID ID: orcid.org/0000-0002-1606-491X

Ainin SULAIMAN is a Professor and Dean at the Social Advancement and Happiness, University of Malaya. She has published papers in Information and Management, Computers in Human Behavior, Telematics, Informatics and Behavior \& Information Technology, and so on. Her research interest includes management information systems, technology diffusion, E-commerce, and green information technology.

ORCID ID: orcid.org/0000-0002-8989-712X

Mohammad NAZRI is a Senior Lecturer at the Faculty of Business \& Accountancy, Universiti of Malaya. He obtained his Doctorate of Business Administration (DBA) from the University Teknologi MARA (UiTM). His research interest includes Management, Organizational Behavior, and Knowledge Management. He has published several books as well as research articles in ISI, Scopus and other refereed journals.

ORCID ID: orcid.org/ 0000-0002-1367-0391

Safiah OMAR is a Senior Lecturer at the Faculty of Business \& Accountancy, Universiti of Malaya. She obtained his PhD in business management from the University Teknologi MARA (UiTM). Her research interest includes Management, Employee Wellbeing and Development, and Happiness at Workplace. She has published various research articles in indexed journals.

ORCID ID: orcid.org/ 0000-0003-1735-5994

Make your research more visible, join the Twitter account of ENTREPRENEURSHIP AND SUSTAINABILITY ISSUES: @Entrepr69728810

Copyright (C) 2020 by author(s) and VsI Entrepreneurship and Sustainability Center

This work is licensed under the Creative Commons Attribution International License (CC BY).

http://creativecommons.org/licenses/by/4.0/

(c) (7) Open Access 